To cite this article: Rosaline O. Opeke, Mercy A. Iroaganachi, Yemisi T. Babalola \& Opeyemi D. Soyemi (2020) Knowledge Sharing Imperatives on STEM Career Path Intentions among Secondary School Students in Northern-Central Nigeria. Information Impact: Journal of Information and Knowledge Management, 11:1, 1-15, DOI: dx.doi.org/10.4314/iijikm.v11i1.1

To link to this article: https://doi.org/10.4314/iijikm.v11i1.1

\title{
Knowledge Sharing Imperatives on STEM Career Path Intentions among Secondary School Students in Northern-Central Nigeria
}

\author{
${ }^{1}$ Rosaline O. Opeke, Mercy A. Iroaganachi, Yemisi, T. Babalola and Opeyemi D. Soyemi \\ ${ }^{1}$ Department of Information Resources Management Babcock University, llisan-Remo, Ogun State
}

\begin{abstract}
The study investigates knowledge sharing as a predictor of STEM career path choice intentions among secondary school girls in NorthCentral Nigeria. The study adopted survey research design. The population comprised 5,433 junior secondary school girls from Federal Government Colleges in the geo-political zone. Multi-stage sampling technique was used to select 361 girls for the study. Instrument for data collection was a validated questionnaire. Data were analyzed using descriptive statistics and binary logistics regression. Findings showed that Knowledge sharing predicted girls STEM career path choice intentions (Cox and Snell $R^{2}=0.025$; Nagelkerke $R^{2}=0.047, p<0.05$ ). The study concludes that secondary school students at the junior level have high intentions to choose STEM career path and that the varied indicators of knowledge sharing predicted STEM career path choice intentions of junior secondary school girls in North-Central Nigeria. It was recommended that secondary school authorities should give incentives and or introduce programmes that will motivate and sustain the students' STEM career intentions such as prizes, awards and recognitions among others for practical projects, quizzes and STEM career debates. Additionally, they should create knowledge sharing opportunities such as playing learning games, group discussions and science clubs for the girls among others.
\end{abstract}

Keywords Knowledge sharing, STEM, career path,

Secondary schools, Career choice intentions

CONTACT Rosaline O. Opeke, Mercy A. Iroaganachi, Yemisi T. Babalola \& Opeyemi D. Soyemi mercy.iroaganachi@covenantuniversity.edu.ng Department of Information Resources Management, Babcock University, IlisanRemo, Ogun State, Nigeria

2020 The Authors Published with License by Information Impact

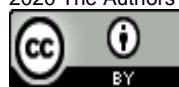




\section{Introduction}

Career Path Choice plays a crucial role in the preparatory educational developmental stage of an adolescent because any choice made at this stage will most likely determine a future career placement. Thus, wrong career choice can result in a waste of an individual's talent and exerting knowledge and energy in the wrong profession. It can also bring about lack of career fulfillment and self-actualization and perhaps not utilizing one's ability maximally. Research has shown that there is gender disparity in STEM career paths as there are more boys than girls in this area of study even though a large proportion of Nigeria's population is female (Wolo, 2018). This situation is largely a reflection of career path choices and decisions of girls that have now culminated in their low subscription to STEM subjects and may not be dissociated from the general perception that STEM education and jobs are for men and not women. STEM education is a teaching and learning system in which science, technology, engineering and mathematics are integrated into varied subject areas. It has the potential to increase comprehension of how things work, boost students' usage of ICT tools as well as introduce them to more engineering courses in precollege education. Accordingly, it is not a prerogative of boys only but depends on students' disposition to STEM subjects and careers, and their choices.

Knowledge sharing is critical to knowledge acquisition which facilitates decisions and choices. However, the common notion about knowledge sharing among peers at the secondary school level is that they do not have much knowledge so there is nothing much to share (Marouf, 2015). The fact is that we live in an information age that is characterized by a society where the emphasis is on universal access. Thus, knowledge on all subjects is immensely available to members of society, irrespective of age, educational status, gender, social status, or qualification. Knowledge sharing in any system has the ability to enhance accuracy of task performance, learning and decision making. When knowledge is shared among peers, the people are empowered while a learning and collaborative culture is developed. In the same vein, the girl-child cannot make informed choices of career path in STEM if there is a dearth of its knowledge and importance among them. Unrealistic career choice among students in the Nigerian institutions of learning may be largely due to insufficient knowledge and information on part of the students

The types of STEM knowledge shared as well as channels through which knowledge is transmitted cannot be underplayed in a discourse on knowledge sharing among secondary school girls. Shared knowledge could be tacit (knowledge that reside within the individuals' head), or explicit (knowledge in books, journals, policies, guidelines, manuals databases). The appropriateness and richness of channel has a huge role to play if STEM career knowledge sharing must be successful (Raychav \& Weisberg, 2010). Knowledge sharing can take place through different channels such as printed materials, face-to-face or digitally (virtual interaction). The nature of knowledge sharing requires a student or group of students to interact with each other either through face-to-face, non-physical contact or by means of contact with printed materials (Hong, Suh \& Koo, 2011; Van-Vuuren, 2011). However, there seem to be more emphasis on virtual channels due to the fact that this is information age. Wynn (2013) posited that social media such as blogging availed students the opportunity to share insight and opinions. Wynn noted that Twitter and Facebook made way for discussions catering for the students' desires to participate in varied activities and helping them not only to express themselves but also communicate their knowledge to peers, friends and relatives and even teachers. Therefore, it behooves stakeholders in institutions of 
learning to create a milieu where both formal and informal methods of knowledge sharing are encouraged by developing effective strategy for knowledge sharing in secondary schools.

Even though there have been several initiatives and efforts targeted at ameliorating the situation, there have not been much success in attempting to fill a reasonable portion of jobs in STEM fields with women. This problem of low female representation in STEM fields could only have been predicated on the career path choice intentions of secondary school girls in the past which may have been due to STEM career knowledge at their disposal thus, culminating in 30\% female representation in STEM globally, 17\% representation in Africa and 25\% in Nigeria (UNESCO, 2017; Ekine \& Negar, 2013). More so, from the researcher's observation and several studies, the challenge of low girls' participation in STEM career paths has not abated. It has become a global issue of concern and discourse. Consequently, it is imperative to know if knowledge sharing can affect STEM career path choice intentions of secondary school girls. Although, some studies have been carried out on gender disparity in STEM in secondary schools, there is none to the best knowledge of the researcher on knowledge sharing, and girls' STEM career path choice intentions especially in North-Central Nigerian. It is on this premise that the study seeks to investigate how knowledge sharing can influence STEM career path choice intentions of secondary school girls in North-Central Nigeria.

\section{Objective of the study}

The general objective of this study is to find out how knowledge sharing practices influence secondary school girls' STEM career path choice intentions in North-Central Nigeria. The specific objectives are to:

1. ascertain STEM career path choice intentions among the secondary school girls;

2. find out if secondary school girls in North-Central Nigeria share knowledge among themselves;

3. determine the level of knowledge sharing among secondary school girls in North-Central Nigeria;

4. ascertain the influence of knowledge sharing on STEM career path choice intentions of secondary school girls in North-Central Nigeria.

\section{Research questions}

This study will seek to provide answers to the following research questions:

1. what are the STEM career path choice intentions of secondary school girls in North-Central Nigeria?

2. do secondary school girls share knowledge among themselves?

3. what is the level of knowledge sharing among girls of secondary schools in North-Central Nigeria?

4. What is the influence of knowledge sharing on STEM career path choice intentions of secondary school girls in North-Central Nigeria?

\section{Hypothesis}

The following null hypotheses will be tested for the study at 0.05 level of significance:

1. knowledge sharing has no significant influence on STEM career path choice intentions of secondary school girls in North-Central Nigeria; 


\section{Literature review}

STEM is an acronym for science, technology, engineering and mathematics. However, the following constitute the broad fields in STEM; computer sciences, engineering, agricultural sciences, biological sciences, ocean and earth, atmospheric, sciences, mathematics and statistics, chemistry, physics, behavioral and social sciences, medical and other health sciences (National Science Foundation, 2018). STEM plays a vital role in modern societies with the possibility of improving lives in a number of ways and advancing the development of nations (Ekine, 2010). Nevertheless, there is a general notion worldwide that STEM education and jobs are for men even though both male and female sexes have same biological capacity to study and succeed in STEM subjects. Thus, efforts are being made to erase that perception and bridge the gender gap that exists in STEM education and professions. One of the ways to ensure that these efforts that are targeted at encouraging girls and young women to participate in STEM, would be to help them situate their career interests and intentions (Association for Progressive Communications [ACT], 2017).

Career path choice intention is a critical decision that is capable of affecting an individual all through his/her life time as it is a complex choice to make requiring a high degree of carefulness and adequate knowledge. This is because there is a vast array of career paths to choose from and if one is not knowledgeable enough to make informed decision, there will be un-envisaged problems (Witherspoon \& Bergner, 2013). Studies revealed that career path choice intentions should be developed from the point of knowledge as lack of adequate information regarding varied careers can result in wrong decisions and choices (Asuquo, 2011; lawer, 2015; Nyamwnge 2016). This is indicative of the fact that there exists a very close relationship between knowledge sharing and career path choice intentions. Sawar and Amaz (2013) discovered that career path choice decisions are not made on standalone basis but are influenced by multiple factors. The major factors that have been identified to influence students' career choice intentions are; interests, self-efficacy and outcome expectations (Edward \& Quinter 2012; Kazi, Nimra \& Nawaz, 2017; Lent, Ireland, Penn, Taylor \& Sappington, 2017). These factors interact with environmental elements to predict academic and vocational choices (Lichtenberger \& Casey, 2013). Thus, in an ideal situation, knowledge should precede any meaningful career path choice intention Pangil \& Aizzat, 2013) citing Fernie, et al. 2003) as a basis for development of interest (Ehigbor \& Akinlosotu, 2016). The reason persons are in professions that they do not derive satisfaction from, is that the choices are void of the right knowledge. According to Manuel and Asuquo (2009), a lot of students pass secondary school stage without choosing their careers because they are confused. Consequently, they apply for tertiary education without real knowledge of the programme they want to pursue.

Since knowledge is critical to decision making and increased performance, as a knowledgefocused activity therefore, knowledge sharing is the fundamental means through which people can contribute to knowledge application, innovation, and ultimately the competitive advantage of the organization (Wang \& Neo, 2010; Moghavvemi, Sharabati, Klobas \& Sulaiman, 2018). In essence, knowledge cannot be accessed except it is shared through varied available avenues. Career guidance is one major way of gaining career knowledge in the education parlance (Wei, Choy, Chew, \& Yen, 2012). Career guidance is intended to educate students about different careers and "help them develop selves for exploring options that can assist them to make correct choices" (Mtemeri, 2017:34). It also helps students identify their own potential and develop it fully (Ogundele \& Feyisetan 2014) thereby making maximum academic benefits as well as instilling confidence and positive attitude (Ajufo, 2013; Omoni, 2013) in pursuing same. In the secondary environment, the people who offer career guidance are: teacher, 
professional guidance and counselors, friends and peers. According to Xue and Larson (2015), some students have difficulty identifying career opportunities and may be underemployed whereas National Academies of Sciences, Engineering, and Medicine (2018) listed women at the top of minority groups in STEM. Thus, knowledge sharing will go a long way to adequately inform girls about STEM careers, job security, retirement plans of the careers and every other necessary information thereby facilitating their career path choice intentions and actual choices (Hewit, 2010). Nyamwange (2016) discovered that having prior knowledge about a career is important to developing and nurturing interest in the career noting that prior knowledge prepares an individual on the requisite conditions for the career. It is interest in any career that will lead to self-actualization, fulfillment and satisfaction. Howbeit, Annansingh, Howell, Liu and Miguel (2018) affirmed that knowledge sharing platform is a veritable one through which girls can gain STEM career knowledge. When girls share STEM career knowledge, their selfefficacy will be well developed and strengthened culminating in a determination to go through the rigor of STEM education being driven by a sense of purpose.

Amani, and Mkumbo (2016) examined the determinants of career intentions among undergraduate students in Tanzania and found that attitude was the strongest predictor of career intentions $(\beta=.47, \mathrm{p})$ compared to other independent variables entered in the model. Also, was revealed that students' career intentions were highly determined by how they perceived their prospective careers meaning that positive perceptions led to stronger behavioural intentions and persistence in performance than negative ones. Zagi, Terungwa and Saanyol (2018) carried out a survey on Correlates of Career Choice among Senior Secondary School Student in Tarka LGA of Benue State, Nigeria. The study revealed that there was no significant difference between male and female students and between students with internal and external locus of control on career choice. Also there was no significant difference between students from uneducated parents and those from educated parents on career choice as well as between students who scored high and low on conscientiousness on career. It was concluded that all the study variables have no relationship with career choice. Also, Marcus (2017) investigated influence of parents, teachers and peer groups on students' choice of business subjects in state government secondary schools in Kaduna state, Nigeria. The study revealed that parents, teachers and peers had significant influence on the choice of Business subjects among secondary school students in the state. More so, Effiom and Petters (2019) carried out a survey on the Determinants of Parental Influence on Career Choice among secondary school students in Cross River State, Nigeria. The study revealed that parental educational background, cultural norms and values, parental occupations, parental expectations and socioeconomic status of parents were among the determinants of parental influence in choosing career for their children.

Furthermore, Olamide and Olawaiye (2013) investigated factors determining the choice of career among secondary school students. Findings of the study showed that secondary school students agreed largely that environmental factors, opportunity and personality factors can influence the choice of career among secondary school students. Durosaro and Adebanke (2012) investigated gender as a factor in the career choice readiness at senior secondary school students in Ilorin, Kwara State. The main findings revealed that male and female secondary school students differ greatly in their career choice readiness. Additionally, Sriratanaviriyakula and El-Dena (2018) examined motivational factors for knowledge sharing among university students during the use of pedagogical discussion cases in and out of the classroom. The results showed that the student's prior knowledge and experience, the lecturer's prior knowledge and experience, including the course context positively influenced the level of knowledge 
sharing while student's self-efficacy, the lecturer's characteristics, and the diversity in team structure do not have significant influence on knowledge sharing.

\section{Methodology}

This research work adopted the survey research design. The total population for this study comprised a total of 5,433 junior secondary school students (JSS2 and JSS3 girls) in all Federal Government Colleges in North-Central Nigeria. Federal Government Colleges were chosen for this study because they are established and run by federal government as well as serve as model colleges. The sample size for this study is 361 JSS2 and JSS3 girls from the North-Central geopolitical zone of Nigeria. The multi-stage sampling technique was used to determine the sample size for this study. The simple random sampling technique was used to select three out of the six states of the zone in addition to FCT (Abuja) making four altogether. Total enumeration was used to include all unity schools in the selected states and FCT, giving a total of 3,613 girls. Taro Yamane (1973) sampling formula was then used to determine the 361 sample size. Afterwards, the proportionate distribution formula was used to distribute the sample across the schools. To determine the actual respondents, a sample frame was sought (registers of the girls in JSS2 and JSS3 classes in the schools) from each stratum (JSS2 or JSS3) in each school. Identification number was assigned to each name on the sample frame and respondents were systematically selected randomly from each stratum. Questionnaire was employed for the collection of data for this study. The questionnaire comprised items on intension to choose STEM career path and the two indices for measuring level of knowledge sharing which are types of knowledge shared and tools of knowledge sharing. The response format for intention to choose STEM career path was dichotomous (Yes/No) while that level of knowledge sharing items followed the four likert scale ranging from Very High $=4$, High $=3$, low $=2$, Very Low $=1$. Data collection was carried out by the researcher and four well briefed research assistants in the study areas. Duration of data collection for the study was one month. The data collected were analyzed using descriptive statistics that is percentage, mean and standard deviation especially for research questions 1-3 while the hypothesis was tested using binary logistics regression analyses.

\section{Results}

Table 1 Distribution of respondents' Age, Secondry School, Class and Religion

\begin{tabular}{l|l|l}
\hline \hline Age & Frequency & Percent \\
\hline \hline $9-11$ & 112 & 31.0 \\
\hline $12-14$ & 246 & 68.1 \\
\hline $15-17$ & 3 & 0.8 \\
\hline Total & 361 & 100.0 \\
\hline Type of seconadary school & Frequency & Percent \\
\hline Private & 310 & 85.9 \\
\hline Public & 51 & 14.1 \\
\hline Total & 361 & 100.0 \\
\hline Class of the students & Frequency & Percent \\
\hline JSS2 & 187 & 51.8 \\
\hline JSS3 & 174 & 48.2 \\
\hline \hline Total & 361 & 100.0 \\
\hline Religion & Frequency & Percent \\
\hline \hline
\end{tabular}




\begin{tabular}{l|l|l}
\hline \hline Christianity & 275 & 76.2 \\
Islam & 86 & 23.8 \\
\hline \hline Total & 361 & 100.0 \\
\hline \hline
\end{tabular}

Table 1 reveals that $68.1 \%$ of respondents were between ages 12 and 14, while $31.0 \%$ were within the age bracket of 9 and 11 years. Only $0.8 \%$ of the respondents belonged to the age range of 15 and 17 years. This implies that majority of girls in junior secondary school were old enough to determine what they desired and would like to do. Also, it was revealed that $85.9 \%$ majority of the respondents attended private primary schools and $14.1 \%$ finished from public primary schools. The implication is that girls in this study had good academic foundation upon which they could build a strong career path in any field of their choice. More so, it was revealed that $51.8 \%$ of respondents were in junior secondary school (JSS 2) while 48.2\% were in JSS 3, meaning that there were more girls in JSS 2 than in JSS 3. Furthermore, findings revealed that $76.2 \%$ of the school girls were Christians while $23.8 \%$ were Muslims. The implication is that majority of the respondents belong to a religion that embraces western education and are more likely to further their education beyond secondary school level, given that all other things remained equal.

Research question 1: what are the STEM career paths choice intentions of secondary schools girls in North-Central Nigeria?

Table 2 STEM career path choice intentions of respondents

\begin{tabular}{|l|l|l|}
\hline $\begin{array}{l}\text { I intend to choose STEM } \\
\text { career path }\end{array}$ & & \\
\hline & Frequency & Percent \\
\hline No & 26 & 7.2 \\
\hline Yes & 335 & 92.8 \\
\hline Total & 361 & 100.0 \\
\hline
\end{tabular}

Table 2 reveals that majority $(92.8 \%)$ of the respondents intend to choose STEM career paths. This finding indicates that the respondents' career path choice intentions are high.

Research Question 2: Do secondary school girls share knowledge among themselves?

Table 3 response on whether respondents share knowledge or not

\begin{tabular}{|l|l|l|}
\hline $\begin{array}{l}\text { Do you share knowledge with your } \\
\text { mates? }\end{array}$ & & \\
\hline & Frequency & Percent \\
\hline No & 1 & 0.3 \\
\hline Yes & 360 & 99.7 \\
\hline Total & 361 & 100.0 \\
\hline
\end{tabular}

Table 3 shows that girls in schools share some knowledge among themselves as $99.7 \%$ of them agreed that they share knowledge which could be tacit or explicit knowledge. This implies that they have knowledge that they can share, discuss and deliberate upon with others thereby encouraging the creation of new knowledge. 
Table 4: level of knowledge sharing among girls of unity secondary schools in North-Central Nigeria VH = Very High, $\mathrm{H}=$ High, L = Low, VL = Very Low

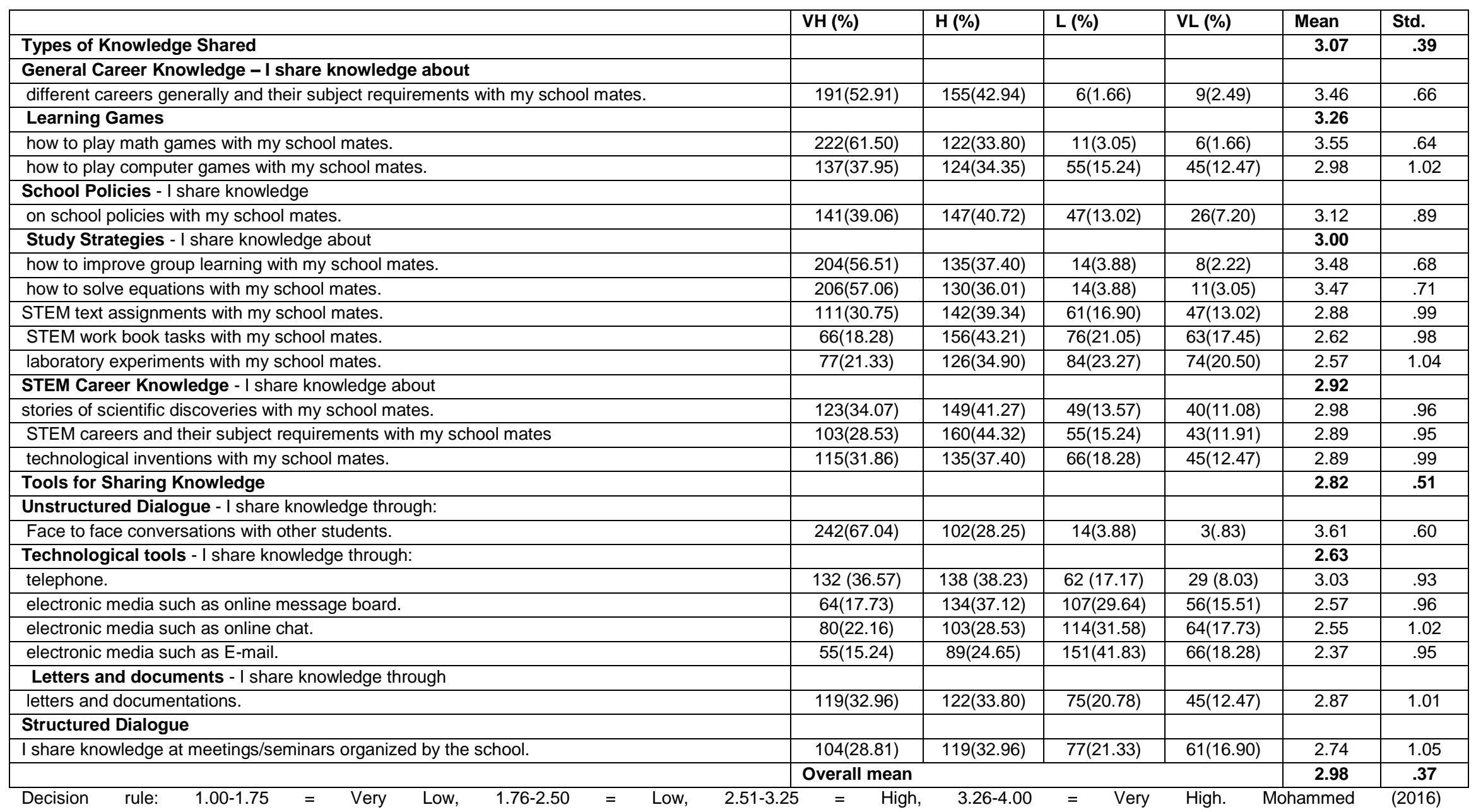


Table 4 shows that the level of knowledge sharing among secondary school girls in North-Central is high, judging by the overall mean score of 2.98 on the scale of 4 . Also, findings reveal that the level of types of knowledge shared is high (mean $=3.07, \mathrm{Std}=.39$ ). Findings on the varied indices for measuring types of knowledge shared by unity secondary school girls in North-Central show that the level of knowledge about different careers generally and their subject requirements is very high (mean $=3.46, \mathrm{Std}=.66$ ), as well as knowledge about learning games with a mean of (3.26). More so, findings show that the level at which respondents shared knowledge on school policies is high (mean $=3.12$, Std $=.89$ ). It was revealed that respondents shared knowledge on study strategies as well as knowledge about STEM careers at a high level with (mean $=3.00$ and 2.92) respectively. Additionally, findings show that the level at which JSS 2and JSS3 girls use different tools for Sharing knowledge is high (mean $=2.82$, Std $=.51$ ). Their level of use of unstructured dialogue is very high with a mean of $(3.61, \mathrm{Std}=.60)$, their use of letters and documents and structured dialogue are high based on (mean $=2.87$ and 2.74 ) respectively. It was discovered that the students used technological tools for sharing knowledge among themselves at a high level $($ mean $=2.63)$. The findings of this study reveal that knowledge on Learning games $($ mean $=3.55$, Std $=.64)$, ideas on how to improve group learning with school mates (mean $=3.48$, Std $=.68$ ) and knowledge on how to solve equations with school mates ( mean $=3.47$, Std $=.71$ ) were specifically more at a very high level.

\section{Test of Hypothesis and interpretation}

This section is a presentation of the null hypothesis on the influence of knowledge sharing on STEM career path choice intentions of secondary school girls in North-Central Nigeria.

$\mathrm{Ho}_{1}$ Knowledge sharing has no significant influence on STEM career path choice intentions of secondary school girls in North-Central Nigeria

Table 4: Binary logistic regression illustrating the influence of Knowledge sharing on girls' STEM career path intentions in secondary schools in North-Central Nigeria

\begin{tabular}{|c|c|c|c|c|c|c|}
\hline Knowledge sharing indices & $\mathrm{B}$ & S.E. & Wald & Sig. & $\operatorname{Exp}(B)$ & $95 \% \mathrm{Cl}$ \\
\hline General Career Knowledge(1) & 0.354 & 0.348 & 1.036 & 0.309 & 1.425 & $0.720-2.815$ \\
\hline \multicolumn{7}{|l|}{ Low (RC) } \\
\hline STEM Career Knowledge(1) & 0.451 & 0.338 & 1.774 & 0.183 & 1.570 & $0.809-3.047$ \\
\hline \multicolumn{7}{|l|}{ Low (RC) } \\
\hline Study Strategies(1) & -0.258 & 0.340 & 0.578 & 0.447 & 0.772 & $0.397-1.504$ \\
\hline \multicolumn{7}{|l|}{ Low $(\mathrm{RC})$} \\
\hline School Policies(1) & 0.080 & 0.412 & 0.037 & 0.847 & 1.083 & $0.482-2.430$ \\
\hline \multicolumn{7}{|l|}{ Low (RC) } \\
\hline Knowledge on Learning Games(1) & -0.468 & 0.409 & 1.307 & 0.253 & 0.626 & $0.281-1.397$ \\
\hline \multicolumn{7}{|l|}{ Low $(\mathrm{RC})$} \\
\hline Technological tools(1) & -0.245 & 0.328 & 0.556 & 0.456 & 0.783 & $0.411-1.490$ \\
\hline \multicolumn{7}{|l|}{ Low $(\mathrm{RC})$} \\
\hline Letters and documents(1) & 0.211 & 0.336 & 0.396 & 0.529 & 1.235 & $0.639-2.388$ \\
\hline \multicolumn{7}{|l|}{ Low (RC) } \\
\hline Unstructured Dialogue(1) & 0.463 & 0.346 & 1.796 & 0.180 & 1.589 & $0.807-3.129$ \\
\hline \multicolumn{7}{|l|}{ Low (RC) } \\
\hline Structured Dialogue(1) & -0.069 & 0.336 & 0.042 & 0.838 & 0.934 & $0.483-1.804$ \\
\hline \multicolumn{7}{|l|}{ Low (RC) } \\
\hline Constant & 1.555 & 0.575 & 7.302 & 0.007 & 4.733 & \\
\hline \multicolumn{7}{|l|}{$\begin{array}{l}\text { Cox \& Snell R Square }=0.025 \\
\text { Nagelkerke R Square }=0.047 \\
-2 \text { Log likelihood }=265.917\end{array}$} \\
\hline \multicolumn{7}{|c|}{$\begin{array}{l}\text { a. Variable(s) entered on step 1: Q132a General Career Knowledge, Q132b STEM Career Knowledge, Q132c Study Strategies, } \\
\text { Q132d School Policies, Q132e Knowledge on Learning Games, Q132f Technological tools, Q132g Letters and documents, Q132h } \\
\text { Unstructured Dialogue, Q132i Structured Dialogue. }\end{array}$} \\
\hline Source: Fieldwork (2019). NB: Refe & 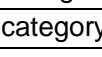 & & & & & \\
\hline
\end{tabular}


The response (or dependent) variable as presented in table 4 is girls' STEM career path choice intentions (GSCPCI) while the predictors are: general career knowledge, STEM career knowledge, study strategies, school policies, knowledge on learning games, tools of knowledge sharing, technological tools, letters and documents, unstructured dialogue, and structured dialogue. Overall, general career knowledge, STEM career knowledge, school policies, letters and documents and unstructured dialogue are positively associated with girls' STEM career path choice intentions but not statistically significant. The variables of Study strategies, knowledge on learning games, technological tools and structured dialogue are negatively related to girls' STEM career path choice intentions. These variables are also not statistically significant.

The specific results indicate that those that share general career knowledge will be 1.425 times more likely to choose STEM career path compared to individuals that indicated 'Low' as response to the question on the level of knowledge sharing with their fellow students $(\mathrm{B}=0.354, \mathrm{p} .0 .05,95 \% \mathrm{CI}$ : 0.720 2.815). Test result on STEM career knowledge reveals also a positive association with girls' STEM career path choice intentions and the students in this category will be 1.570 times more likely to choose STEM career path compared to individual that indicated 'Low' as response to the question on the level of knowledge sharing about STEM careers and their subject requirements with their fellow students $(\mathrm{B}=$ 0.338, p.0.05, 95\%CI: $0.809-3.047)$. Students that share knowledge about school policies are 1.083 times more likely to have intention to choose STEM career path compared to those who responded low to the question ( $\mathrm{B}=0.080, \mathrm{p}>0.05 ; 95 \% \mathrm{CI}$ : 0.482-2.430). Similar results were obtained for letters and documents $(\mathrm{B}=0.211, \mathrm{p}>0.05$; 95\%CI: 0.639-2.388) and unstructured dialogue $(\mathrm{B}=0.463, \mathrm{p}>0.05$; 95\%CI: 0.807-3.129). However, respondents who used letters and documents and unstructured dialogue will be 1.235 and 1.756 times more likely to have intention to choose STEM career path respectively compared to their colleagues who signified low to the question. The general model summary indicate that these variables put together will exert 2.5 or $4.7 \%$ influence on the students' intention to choose STEM career path $($ Cox \& Snell R Square $=0.025$; Nagelkerke R Square $=0.047)$.

\section{Discussion}

Response to research question one revealed that majority $(92.8 \%)$ of the respondents intend to choose STEM career path. This implies that secondary school girls have interest in STEM careers. The secondary schools girls' interests in STEM career path may have been informed by several other factors that interacted with their self-efficacy and/or outcome expectation apart from those found in this study. Sawar and Amaz (2013) confirmed that career path choice intentions are not made on standalone basis but are influenced by multiple factors. Lent, Brown, and Hackett (1994) and Bandura (1986) in their theories of social cognitive career theory and social cognitive theory, supported by other authors, asserted that career choice intentions are developed by interests that are informed by "self-efficacy" Lent, Ireland, Penn, Taylor and Sappington (2017) and Sawar and Azmat (2013) "outcome expectations" Lichtenberger and Casey (2013) and their interactions with environmental factors to predict academic and vocational choices. Also, this result means that the girls have some knowledge about the STEM career path that they desire to follow or take up. According to Nyamwnge (2016) and Ehigbor and Akinlosotu (2016), sufficient career knowledge is required by the students to properly situate their interest in the career path to choose. This is due to the fact that interest void of knowledge can be short lived (Higgins, Dewhurst \& Walkins, 2012). 
The responses to research question two show that girls in junior secondary schools do share some kinds of knowledge among themselves as $99.7 \%$ of them agreed that they share knowledge. The level at which they shared different types of knowledge is high, judging by the overall mean score of 2.98 on the scale of 4 . The types of knowledge shared among the girls are knowledge about different careers generally and their subject requirements (mean =3.07). Also the girls shared knowledge on learning strategies such as knowledge about ideas on how to improve group learning, knowledge on how to solve equations, knowledge on school policies as well as knowledge about STEM careers and their subject requirements. This finding contradicts the claim by Moghavvemi, et al (2018), and Pangil and Aizat (2013), that individuals hoard knowledge or are reluctant to share knowledge due to reasons like; competition, pride, desire to exercise knowledge power over others, the fear of decreased personal value and uncertainty of how the receiver will use the shared knowledge.

The fact that secondary school girls shared knowledge at a high level means that junior secondary school girls have general career knowledge including STEM career which occasioned the high level of sharing same as Yaghi, Barakat, Alfawaer Shkokani and Wynn (2013) confirmed that students and other individuals in their different endearvours share knowledge that is existent in them. This finding negates Marouf (2015)'s claim that older folks who are more experienced have a higher disposition towards knowledge sharing. Junior secondary school students (respondents in this study), are predominantly between ages 9-12 yet they were involved in Knowledge sharing.

In addition to the foregoing, findings of this study revealed that respondents shared knowledge on learning games such as how to play math games and computer games. This is an indication that respondents owned learning skills, expertise and experiences that they shared among themselves as Pangil and Aizzat (2013), citing Fernie, et al. (2003), argued that knowledge is extremely personal and entrenched in definite social settings. Sharing knowledge on learning games is one vital avenue of releasing individuals' experiences and Witherspoon and Bergner (2013), noted that sharing skills, experiences, know-how or expertise has Mutual benefits which invariably promote behaviors, Cultural change Lee (2018), and create new knowledge (Nonaka, 1994 cited by Pangil \& Aizzat, 2013). Wei, Choy, Chew, and Yen (2012) confirmed this when they asserted that knowledge sharing among students was an important learning activity that is beneficial to both the sharer and the receiver. Rusu and Avasilcai (2014) and Panahi, Watson, and Partridge (2012) went further to posit that knowledge sharing is the exchange of information, opinions, skills, experiences, know-how and ideas through collecting and donating processes.

The result of this study also showed that the employment of different knowledge sharing tools among junior secondary school girls is high (average $=2.82$ ). In the same vein, it is noteworthy that the level at which respondents used unstructured tool (face to face conversations) and telephone is very high. This implies that the girls find these tools more convenient and effective for sharing knowledge, corroborating the findings of Wynn (2013) Hong, Suh and Koo, (2011) who referred to face to face interactive tool as primitive but one of the most effective channels of sharing expertise and task oriented knowledge. The very high level of deploying unstructured Knowledge sharing tool must stem from the types of knowledge (knowledge on learning games and study strategies i.e. expertise, experiences and skills) that students shared at a very high level based on the claims of Pangil and Aizzat (2013). Raychav and Weisberg (2010) rightly noted that the tool used for sharing knowledge must be appropriate as it determines the success of the activity to a great extent. 
The test result of hypothesis one at multivariate level as presented in table 4, indicated that sharing General career knowledge and knowledge about STEM careers and their subject requirements, study strategies, school policies and knowledge on learning games, have no significant influence on STEM career path choice intentions of unity junior secondary school girls. Nevertheless, general career knowledge and knowledge about STEM careers and their subject requirements and sharing knowledge on school policies have positive relationship with the dependent variable. The descriptive statistics revealed that respondents' level of knowledge sharing is high however; it is not statistically strong enough to have significant influence on the girls' career path choice intentions. This situation could have been occasioned by varied factors such as interaction and interference of variables, the amount of knowledge which the students shared, the adequacy of knowledge shared their disposition (trust and perception) toward knowledge shared, application of knowledge received and institutional culture or environment.

The level at which respondents shared knowledge was not very high and it is a function of the amount of knowledge the girls possess. If they had much career knowledge, especially STEM career knowledge then they would have had so much knowledge to share as students cannot share the knowledge that they do not have or have gained. Lee (2018) Nyamwange (2016), Pangil and Aizzat (2013), citing Fernie, et al. (2003), and Panahi et al (2012) asserted that knowledge sharing involves releasing owned knowledge which exists in the minds of individuals to others. Lee and Hong (2014) concluded that the more knowledge a possessor holds, the stronger his/her knowledge sharing intention becomes.

Also, the adequacy of shared knowledge critical for significant influence could have warranted the result of test of hypothesis one. The implication is that specific knowledge is fundamental to its application to the issue needing it, in order to get the desired outcome. The descriptive statistics showed that girls in secondary schools shared knowledge at a high level, however the direction and adequacy of what was shared is not known; could it be that knowledge shared was negative instead of raising the aspirations of fellow students? Ogundele and Feyisetan (2014), Lawer (2015) Hewit (2010) Nyamwange (2016), Asuquo (2014) and Raychav and Weisberg (2010) opined that adequate information is an essential component of the educational system to facilitate students' choices or decisions in the selection and appropriate combination of subjects or courses that best suit their aptitudes and aspirations for the future world of work.

Non application of knowledge shared or received can be major determinant of the non-significant influences of the types of knowledge sharing indices on girls' STEM career path choice intentions. Knowledge is supposed to be used but when it is not used, it cannot bring about the desired result. It was revealed that unity secondary school girls in North-Central Nigeria shared different types of knowledge but the question is, did they apply the received knowledge and did they apply it correctly? Wang \& Neo, (2010), Ogundele and Feyisetan (2014) Ajufo (2013) and Omoni (2013) affirmed that knowledge sharing is an application targeted activity for continued growth, change and development. Therefore, for any acquired knowledge to be impactful, it has to be applied correctly.

Concerning tools for sharing knowledge, the test result showed that letters and documents and unstructured dialogue are positively associated with girls' STEM career path choice intentions but not statistically significant while technological tools and structured dialogue are negatively related without significant influence on GSCPCI. The implication of this result is that although participants deployed letters and documents and unstructured dialogue tools at a level that is not significant, they were more disposed to using them. This explains why unstructured dialogue was the only index that was deployed at a very high level as shown by the descriptive statistics. The two tools are the basic and most common among humans including the respondents. Delio, Pardo and Toulson, (2015) referred to letters and 
documents as being traditional to man and cannot go out of use while Wynn (2013) referred to unstructured tool (face to face) as primitive but preferred and remains one of the effective channels of formally or informally talking about experiences, challenges, projects, and shared opinions as well as take decisions. Technological and Structured dialogue tools were negatively related and had no significant influence on GSCPCIs may be due to the special conditions and technical skills required for deploying them (Abdollahtan, Mehdi \& Ahmadi, 2013). The implication of the other findings and hypothesis that was tested in this study is that all the indices of the independent variable are capable of influencing the dependent variable given the ideal situation and environment.

\section{Conclusion and recommendations}

The study concludes that secondary school students at the junior level have high intentions to choose STEM career path. It established that varied indicators of knowledge sharing can predict STEM career path choice intentions of junior unity secondary school girls in North-Central Nigeria. Also, possession of adequate STEM career knowledge is critical to junior secondary school girls' sharing of the right knowledge, make informed decisions as well as increase the girls' STEM career path choice intentions and enrolment. Secondary school girls share knowledge through unstructured dialogue and letters/documents more than through other tools. Therefore, secondary school management are encouraged to give incentives and or introduce programmes that that will motivate and sustain the students' STEM career intentions such as prizes, Awards and recognitions among others for practical projects, quizzes and STEM career debates. There is also the need for Secondary school authorities, NGOs, Career counselors and other stakeholders in the education sector to adequately and constantly educate and orientate girls about STEM careers and the subject requirements so that they can have variety of STEM knowledge, share the right knowledge with their peers and make informed decision. More so, it is recommended that secondary school authorities should create knowledge sharing opportunities such as playing learning games, group discussions and science clubs for the girls. Finally, secondary school girls are encouraged to share knowledge through technological tools as the era demands.

\section{References}

Ajufo, B.I. (2013). Challenges of youth unemployment in Nigeria: Effective career guidance as a panacea. An International Multidisciplinary Journal Ethiopia, 7(1), 307-319.

Annansingh, F., Howell, k.E., Liu, S., Miguel, B.N. (2018) Academics' perception of knowledge sharing in higher education. International Journal of Educational Management, 32(6), 1001-1015, https://doi.org/10.1108/IJEM-07-2016-0153.

Association for Progressive Communications (APC) (2017). Bridging the gender digital divide from a human rights perspective: APC submission to the Office of the High Commissioner for Human Rights. Available at:https://www.ohchr.org/Documents/Issues/Women/WRGS/GenderDigital/APC.pdf

Asuquo, A.I. (2011). Factors that influence accounting as career choice of Nigerian university students in the 21st century. The Certified National Accountant, 34-38.

Delio, I.C., Pardo, C. \& Toulson, P. (2015). A Spanish knowledge sharing instrument validation. Electronic Journal of Knowledge Management, 13(1), 3-10.

Durosaro, I. \& Adebanke, N.M. (2012). Gender as a factor in the career choice readiness of senior secondary school students in Metropolis of Kwara state Nigeria. International 
Journal of Humanist and Social Science, 2(14):109-113.

Edwards, K. \& Quinter, M. (2012). Factors influencing students career choices among secondary school students in Kisumu Municipality, Kenya. Journal of Emerging Trends in Educational Research and Policy Studies, 2(2),81-87.

Ehigbor, B. \& Akinlosotu, T.N. (2016). Parents' occupation as correlate of students' career aspiration in public secondary schools in Ekpoma Metropolis. International Journal of Arts and Humanities, 5(3):197-212.

Ekine, A.O. (2010). The impact of videotaped instructional strategy on pupils' interest and achievement on primary science in some selected schools in Oyo state," (PhD thesis, University of Ibadan.

Ekine, A. \& Negar, A.A. (2013). Enhancing girls' participation in science in Nigeria: a driver for national development and social equality.

Hong, D., Suh, E. \& Koo, C. (2011). Developing strategies for overcoming barriers to knowledge sharing based on conversational knowledge management: a case study of a Financial company. Expert systems of applications, 38(12), 14417-144.

Iroagnanchi, M.A., Nkiko, C. \& Eni, A. (2017). Heath information, perception and demographic variables as correlates of gender equality in science, technology, engineering and math (STEM) education in South-West Nigeria. Annals of Global Health 83 (1), 104.

Kazi, A.A., Nimra, S. \& Nawaz, A. (2017). Factors Influencing Students' Career Choices: Empirical Evidence from Business Students. Journal of Southeast Asian Article ID 718849, DOI: $10.5171 / 2017.718849$.

Lee, J. (2018). The effects of knowledge sharing on individual creativity in higher education institutions: Socio-technical view. Administrative Sciences, 8(21), 1-16.

Lent, R.W., Ireland, G.W., Penn, L.T., Taylor, R.M. \& Sappington, R. (2017). Sources of self-efficacy and outcome expectations for career exploration and decision-making: A test of the social cognitive model of career self-management. Journal of Vocational Behaviour (99), 107-117. Available at: https://www.sciencedirect.com/science/article/pii/S0001879117300015

Lichtenberger, E. \& Casey, G.J. (2013). Predicting high school students' interest in majoring in a stem field: insight into high school students' postsecondary plans. Journal of Career and Technical Education, 28 (1), 19-38.

Manuel, A.M. \& Asuquo, P.N. (2009). Near-school leaders' perceptions of their vocational and labour market information needs. Stud Home Comm Sci, 3(2),135-142.

Moghavvemi, S., Sharabati, M., Klobas, J.E. \& Sulaiman, A. (2018). Effect of trust and perceived reciprocal benefit on students' knowledge sharing via Facebook and academic performance. The Electronic Journal of Knowledge Management, 16(1), 23-35. Available online at www.ejkm.com

Mohammed, A. (2016). Which method should I use to present the Mean of a 5-point Likert scale? Available

at: https://www.researchgate.net/post/Which_method_should_I_use_to_present_the_Mean_of_a_5point_Likert_scale

Mtemeri, J. (2017). Factors influencing the choice of career pathways among high school students in midlands province, Zimbabwe. Being a Thesis submitted in accordance with the requirements for the award of the degree of Doctor of Education, Department of Psychology of Education, Faculty of Education, University of South Africa..

National Science Foundation [NSF] (2018). NSF FY 2018 budget request to congress. 
Available at: https://www.nsf.gov/about/budget/fy2018/pdf/01_fy2018.pdf

Ogundele, A.G. \& Feyisetan, C.T. (2014). Impact of vocational guidance in addressing the choice of vocational and technical education among nigeria youth. Open Science Journal of Education, 2(5), 56-60.

Omoni, D.G. (2013). Moving with times taking a global approach: A Qualitative study of African student nurse views of e-learning. Nurse Education Today.

Pangil, P. \& Aizzat, M.N. (2013). Knowledge and the importance of knowledge sharing organizations. 349-361.

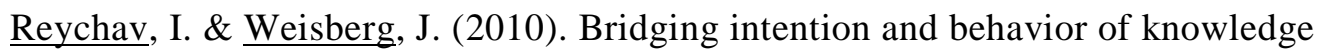

Sharing. Journal of Knowledge Management, $\quad 14(2), \quad 285-$ 300, https://doi.org/10.1108/13673271011032418

Rusu, G. \& Avasilcai, S. (2014). Contextual factors and knowledge sharing motivation: A research framework. Advanced Materials Research, 1049-1054.

Sarwar, A. \& Azmat, A. (2013). Factors having impart on the career decisions: Study of business graduate in Pakistan, Management Dynamics, 2(7), 9-19.

UNESCO (2017). New UNESCO report sheds light on gender inequality in STEM education available at: file://C:/Users/user/Desktop/New\%20UNESCO\%20report\%20sheds\%20light\%20on\%20gender $\%$ 20inequality\%20in\%20STEM\%20education.htm

Van-Vuuren, S.J. (2011). Inter-Organisational knowledge sharing in the public sector: the role of social capital and communication technology. Doctoral thesis, Victoria University of Wellington, School of Information Management, 2011.

Wang, S. \& Neo, R.A. (2010). Knowledge sharing: A review and directions for future research. Human Resource Management Review, 20 115-131.

Wei, C.C., Choy, C.S., Chew, G.G. \& Yen, Y.Y. (2012). Knowledge sharing patterns of undergraduate students. Library Review 61 (5), 327-344.

Witherspoon, C., \& Bergner, J. (2013). Antecedents of organizational knowledge sharing: A meta-analysis and critique. Journal of Knowledge ... Retrieved from http://www.emeraldinsight.com/journals.htm?articleid=17083211\&show=abstract.

Wolo, T. (2018). Advancing women in academia and industry: Strategies, policies and emerging issues in the $21^{\text {st }}$ century. A keynote address at the $1^{\text {st }}$ International Women's Multidisciplinary Conference CU-IWMC 2018 held at the African Leadership Center (ALDC) September, 11-12. 